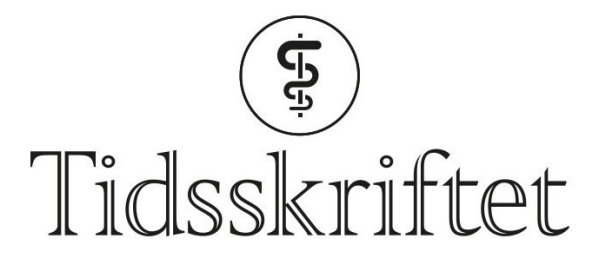

DEN NORSKE LEGEFORENING

\title{
Delprotese eller totalprotese ved hoftebrudd?
}

FRA ANDRE TIDSSKRIFTER

PETTER MORTEN PETTERSEN

Tidsskriftet

Delprotese er like bra som totalprotese ved lårhalsbrudd med feilstilling hos eldre. Dette viser en stor randomisert studie med et betydelig norsk bidrag.

Illustrasjon: Sittithat Tangwitthayaphum / iStock

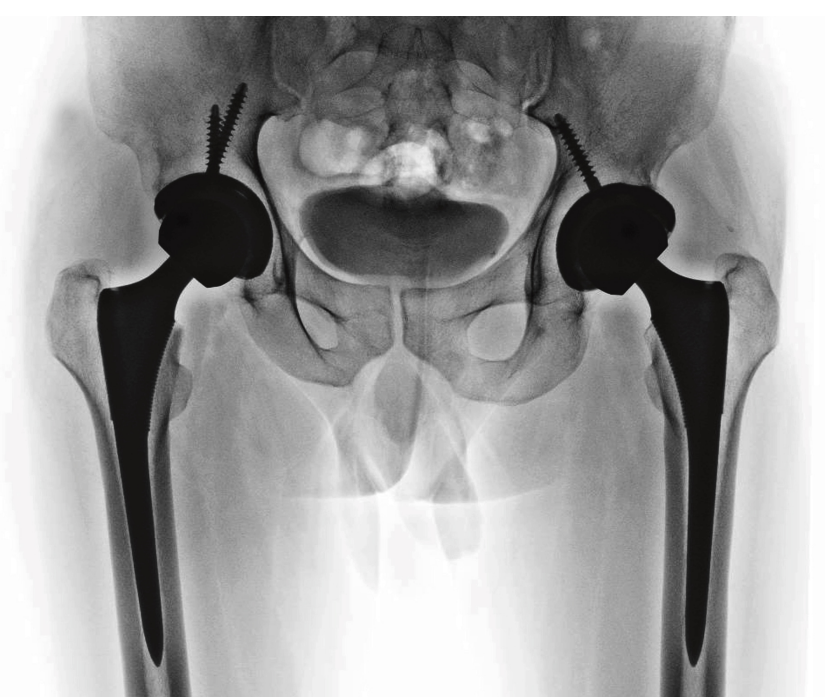

Bør oppegående eldre pasienter med lårhalsbrudd opereres med totalprotese eller delprotese? Gjeldende oppfatning er at totalprotese vil gi et bedre funksjonelt resultat sammenlignet med delprotese.

I en stor multisenterstudie ble 1495 pasienter over 50 år som fra tidligere var mobilisert uten manuell støtte, randomisert til behandling med totalprotese eller delprotese. Snittalderen på pasientene var 79 år, og 70 \% var kvinner. Kun erfarne kirurger opererte. Pasientene ble rekruttert fra 8 o sykehus i 10 land, og Oslo universitetssykehus var det største senteret (1).

Etter to år var det ingen forskjell $\mathrm{i}$ andelen pasienter som måtte reopereres, dvs. 7,9\% i totalprotesegruppen og 8,3\% i delprotesegruppen. Det var heller ingen forskjell i dødelighet etter ett år, henholdsvis 14,3\% og 13,1\%. Smerte, bevegelighet og funksjon i hoften var statistisk signifikant bedre i totalprotesegruppen, men forskjellene var mindre enn det som ble vurdert å være klinisk relevant. 


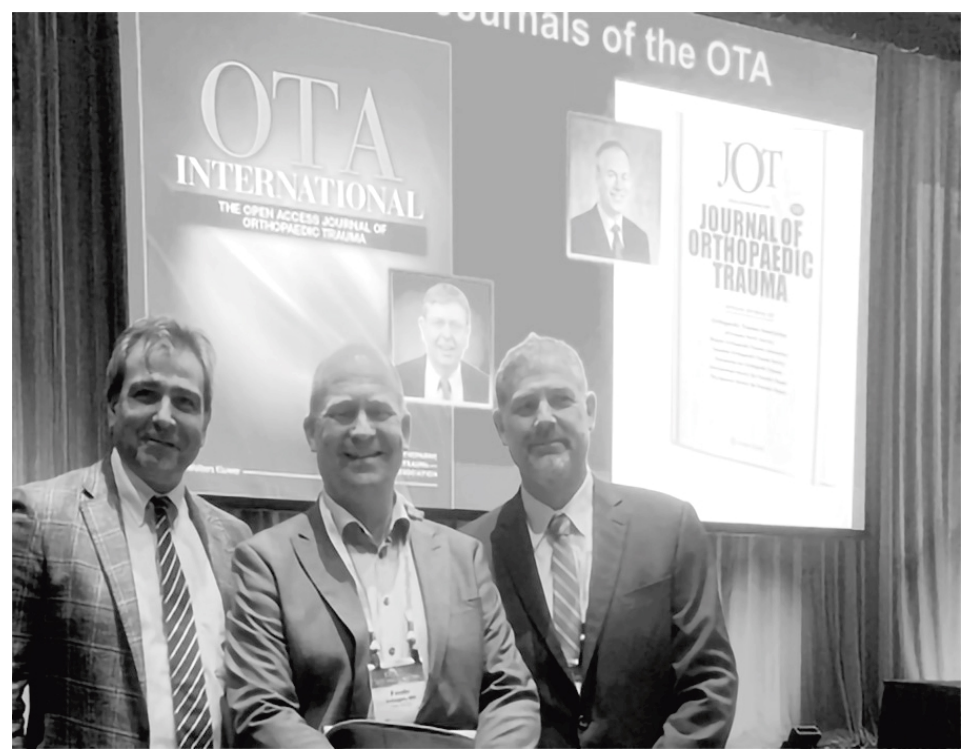

Fra venstre: Mohit Bhandari, professor i ortopedi ved McMaster-universitetet $i$ Canada og leder for styringsgruppen og initiativtager til studien; Frede Frihagen, overlege ved Oslo universitetssykehus og medlem av styringsgruppen og studieleder $i$ Norge; og Robert Zura, professor i ortopedi $i$ New Orleans og leder i komiteen som kvalitetssikret studiens primcerendepunkt. Foto: Sheila Sprague

- Denne studien viser at eventuelle fordeler med totalprotese for hjemmeboende ambulante eldre med lårhalsbrudd med feilstilling ikke er så store som tidligere antatt, sier Frede Frihagen, som er overlege ved Ortopedisk avdeling, Oslo universitetssykehus og medlem av styringsgruppen og studieleder i Norge. Han mener at de fleste, om ikke alle, av disse pasientene kan opereres med delprotese.

Hoftebrudd er et av de ti viktigste helseproblemene i verden. I Norge får hvert år rundt 9 ooo personer hoftebrudd, og omtrent halvparten av disse er lårhalsbrudd. Pasientene risikerer å miste evnen til å klare seg selv. Dødeligheten etter ett år er 20-25\%. Rask og skånsom kirurgisk behandling med lav risiko for komplikasjoner og nye operasjoner er viktig for å sikre en best mulig prognose, sier Frihagen.

- Det har vært publisert flere mindre studier som tyder på at relativt spreke pasienter med lårhalsbrudd med feilstilling kan få bedre funksjon og ha lavere risiko for reoperasjoner hvis de opereres primært med en totalprotese. Norske og internasjonale retningslinjer anbefaler derfor at hjemmeboende og godt fungerende pasienter opereres med totalprotese. Denne studien, med sitt store antall pasienter og metodiske kvalitet, er viktig for å vurdere valg av protese til pasienter med lårhalsbrudd med feilstilling, sier Frihagen.

LITTERATUR:

1. Bhandari M, Einhorn TA, Guyatt G et al. Total hip arthroplasty or hemiarthroplasty for hip fracture. N Engl J Med 2019; 381: 2199-208. [PubMed][CrossRef]

Publisert: 2. januar 2020. Tidsskr Nor Legeforen. DOI: 10.4045/tidsskr.19.0644

(C) Tidsskrift for Den norske legeforening 2020. Lastet ned fra tidsskriftet.no 